\title{
Teased fibre study of early nerve lesions in leprosy and in contacts, with electrophysiological correlates
}

\author{
V.P. SHETTY, L. N. MEH T A, N. H. A N T I A, A N D P. F. IR A N I \\ From the Tata Department of Plastic Surgery, Department of Anatomy of Grant Medical College, \\ and Department of Electrodiagnosis, JJ Group of Hospitals, Bombay, India
}

SUMMARY A teased fibre technique was used to study 19 biopsies of the index finger branch of the radial cutaneous nerve of leprosy patients and contacts. These were compared with four normal nerves. Five nerves were from patients with preclinical nerve lesions, five from leprosy patients with minimal sensory nerve impairment, and five from contacts of lepromatous leprosy. The extent of demyelination in preclinical nerve lesions in leprosy and in contacts of leprosy is recorded. The usefulness of nerve conduction velocity studies in early leprosy patients and in contacts is discussed.

The study of peripheral nerve by the teased fibre technique has been well established in healthy individuals (Lascelles and Thomas, 1966; Arnold and Harriman, 1970), in experimental neuropathy, and in different neuropathies of man (Dyck et al., 1968). The presence of segmental demyelination in nerves in early leprosy irrespective of its type has been reported by Antia et al. (1975) and Mehta et al. (1975). Dastur and Razak (1971) state that segmental demyelination is very common in lepromatous leprosy and Wallerian degeneration is common in the tuberculoid variety. The extensive damage in tuberculoid leprosy is believed to be related to the severity of the cellular reaction. No teased fibre study of very early nerve lesions in leprosy has been reported. We have studied the morphology of nerve fibre degeneration by the teased fibre technique at the early clinical and preclinical stage of nerve involvement.

\section{Material and method}

The index finger branch of the radial cutaneous nerve was biopsied by the technique previously described (Antia et al., 1975). The 19 nerves were divided into four groups:

Group I Four nerves from normal healthy volunteers between the ages of 17 and 32 years.

Address for reprint requests: Dr N. H. Antia, Head, Tata Department of Plastic Surgery, Balaram Building, JJ Group of Hospitals, Bombay, 400008 , India.

Accepted 1 February 1977
Group II Five nerves obtained from leprosy patients who had no sensory loss to temperature, pain, touch, and pressure, and two point discrimination over the territory supplied by the above-mentioned nerve.

Group III Five nerves from leprosy patients who showed minimal sensory impairment in this nerve territory.

Group IV Five nerves obtained from the contacts of lepromatous leprosy patients, who were clinically and bacteriologically not suffering from leprosy. We have described the method for estimating the conduction velocity of this nerve (Antia et al., 1975) and values were in the lower limit of normal or marginally reduced in this group.

Nerve samples were collected and fixed in glutaraldehyde, post-fixed in buffered $\mathrm{OsO}_{4}$, and processed by a standard electron microscopy technique. Each nerve was dissected using a Ziess dissecting microscope at magnification $\times 20$. The nerve sampled had mostly one large and one small funicle. Each funicle was teased out in a drop of Araldite and individual fibres were placed on a glass slide. Fibres of varying calibres were picked up randomly for examination. Fifty fibres were mounted for each sample. The diameter of each fibre at different levels was measured, and the mean value was taken. Internodal length was also measured. Abnormalities including number of degenerating, demyelinating, or regenerating segments were noted, and the results were tabulated. 


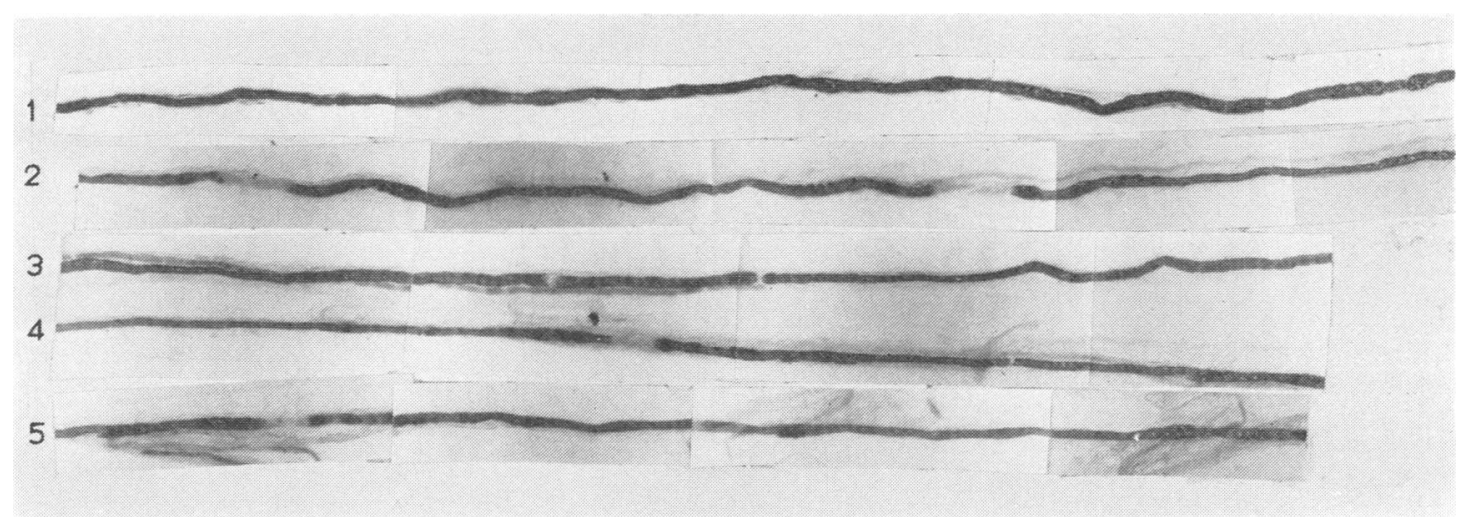

Fig. 1 Consecutive lengths from top to bottom of a teased myelinated fibre showing demyelinated internodes, and a significant variation in internodal distance suggestive of remyelination following demyelination. Nerve from a patient of Group II. Glutaraldehyde plus osmium fixed nerve $\times 280$.

\section{Observations}

Figure 1 illustrates the type of segmental demyelination observed. The incidence of segmental demyelination and Wallerian degeneration in the various groups is given in Tables 1-4. A highly significant proportion of demyelinating fibres $(20 \%)$ were seen in patients of Group II as compared with controls of Group I (5\%). Wallerian degeneration was within normal limits in these two groups of cases.
Compared to Group I, in Group II the sensory conduction velocity in the large and average sized fibres, as determined by latency to onset and latency to peak of the evoked sensory action potential (Buchthal and Rosenfalck, 1966, 1971) was either in the lower limit of normal or slightly reduced (Tables 1 and 2 ).

Segmental demyelination was greater in Group III where the nerve was clinically affected. In this group Wallerian degeneration was also seen simultaneously (Fig. 2). Commensurately the nerve con-

Table 1 Group I (normal controls)

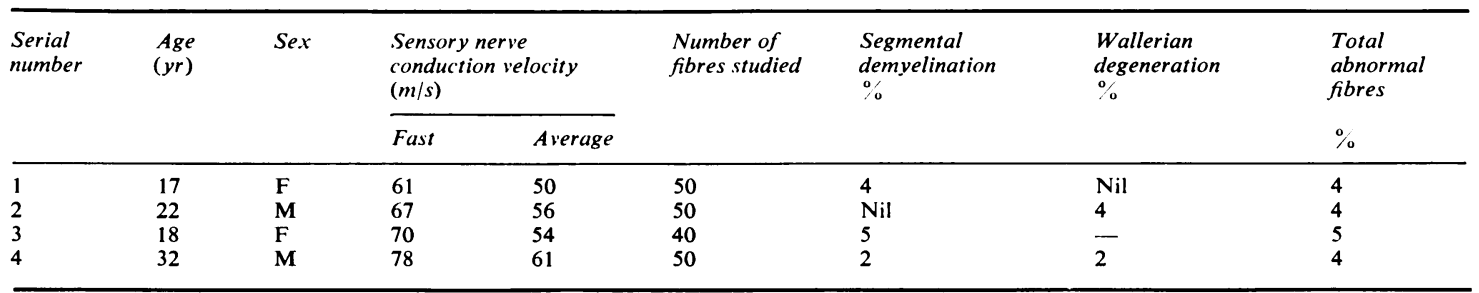

Table 2 Group II (Radial cutaneous nerve-index branch-from leprosy patients when the area supplied by the nerve was clinically normal)

\begin{tabular}{|c|c|c|c|c|c|c|c|c|c|}
\hline \multirow[t]{2}{*}{$\begin{array}{l}\text { Serial } \\
\text { number }\end{array}$} & \multirow[t]{2}{*}{$\begin{array}{l}\text { Age } \\
(y r)\end{array}$} & \multirow[t]{2}{*}{ Sex } & \multirow[t]{2}{*}{$\begin{array}{l}\text { Type } \\
\text { of } \\
\text { leprosy }\end{array}$} & \multicolumn{2}{|c|}{$\begin{array}{l}\text { Sensory nerve } \\
\text { conduction velocity } \\
(\mathrm{m} / \mathrm{s})\end{array}$} & \multirow[t]{2}{*}{$\begin{array}{l}\text { Demyelination } \\
\%\end{array}$} & \multirow[t]{2}{*}{$\begin{array}{l}\text { Wallerian } \\
\text { degeneration } \\
0\end{array}$} & \multirow[t]{2}{*}{$\begin{array}{l}\text { Number } \\
\text { of } \\
\text { fibres }\end{array}$} & \multirow{2}{*}{$\begin{array}{l}\text { Total } \\
\text { abnormal } \\
\text { fibres } \\
\% \\
\%\end{array}$} \\
\hline & & & & Fast & Average & & & & \\
\hline 1 & 34 & $F$ & BT & 67 & 54 & 18 & 0 & 50 & 18 \\
\hline 2 & 34 & $\mathbf{F}$ & BT & 67 & 54 & 20 & 0 & 50 & 20 \\
\hline 3 & 25 & $\mathbf{M}$ & BT & 61 & 52 & 20 & 0 & 40 & 20 \\
\hline 4 & 25 & $\mathbf{M}$ & TT & 61 & 50 & 20 & 0 & 50 & 20 \\
\hline 5 & 19 & $\mathbf{M}$ & BT & 58 & 49 & 17 & 0 & 50 & 17 \\
\hline
\end{tabular}

TT = tuberculoid type of leprosy; BT = borderline tuberculoid; BB = borderline type of leprosy; $\mathbf{B L}=$ borderline lepromatous; $\mathbf{L} \mathbf{L}=$ lepromatous leprosy. This is Ridley Jopling's classification of leprosy (1966) which is universally accepted. 


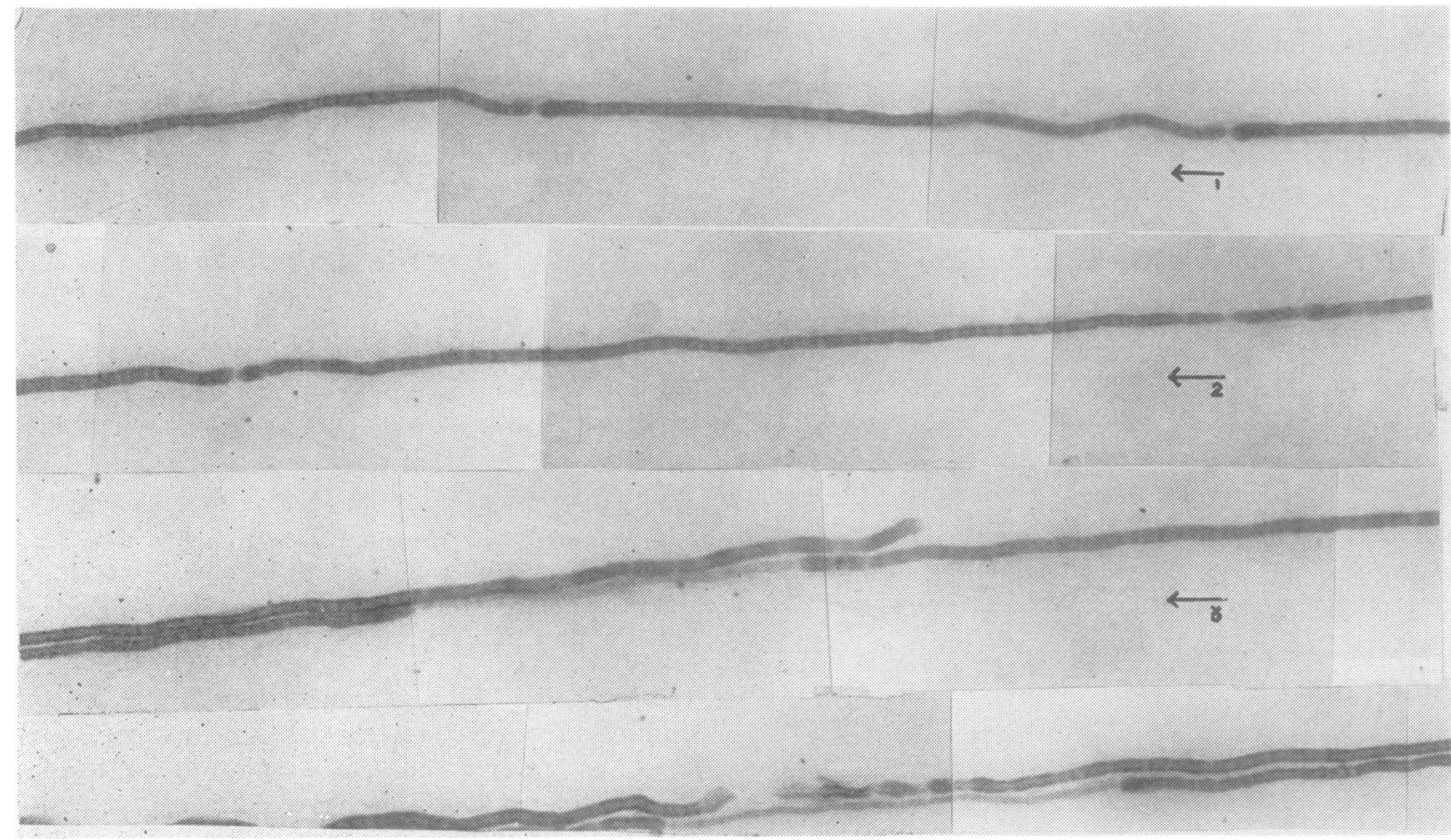

Fig. 2 Teased fibre preparation of Fibre No. 1, showing one very small internode with thinner myelin, the other larger internode showing myelin globules. Four other fibres also show nodal demyelination and myelin globules in places. Nerve from patient of Group III. Glutaraldehyde plus osmium fixed nerve $\times 250$.

duction velocity was clearly more impaired than in Group II (Tables 2 and 3). In Group IV (Table 4) the nerves of clinically unaffected contacts of lepromatous leprosy showed segmental demyelination but to a lesser degree than in Group II. It is noteworthy that in all these contacts, nerve conduction velocity was minimally but significantly reduced.

\section{Discussion}

In the histopathological studies of nerves in advanced leprosy, Job (1971) and Dastur and Razak (1971) observed that in the lepromatous variety segmental demyelination predominated, while in the tuberculoid type Wallerian degeneration was principally seen, resulting from extensive cellular proliferation. Our observations show that in early leprosy, regardless of the type, segmental demyelination predominates as seen in our Group II ( $20 \%$ of fibres). Wallerian degeneration appeared only later in the course of the disease, and both types of degeneration were seen concomitantly in Group III.

Slowing of nerve conduction is a reflection of demyelination rather than axonal degeneration, and our own studies have clearly demonstrated a stepwise reduction in nerve conduction velocities in the order Group I, IV, II, and III.

Our observations suggest that a careful (and

Table 3 Group III (Radial cutaneous nerve-index branch-from leprosy patients where the area supplied by the nerve was minimally affected clinically)

\begin{tabular}{|c|c|c|c|c|c|c|c|c|c|}
\hline \multirow[t]{2}{*}{$\begin{array}{l}\text { Serial } \\
\text { number }\end{array}$} & \multirow[t]{2}{*}{$\begin{array}{l}\text { Age } \\
\text { (yr) }\end{array}$} & \multirow[t]{2}{*}{ Sex } & \multirow[t]{2}{*}{$\begin{array}{l}\text { Type } \\
\text { of } \\
\text { leprosy }\end{array}$} & \multicolumn{2}{|c|}{$\begin{array}{l}\text { Sensory nerve } \\
\text { conduction velocity } \\
(\mathrm{m} / \mathrm{s})\end{array}$} & \multirow[t]{2}{*}{$\begin{array}{l}\text { Number } \\
\text { of } \\
\text { fibres }\end{array}$} & \multirow[t]{2}{*}{$\begin{array}{l}\text { Segmental } \\
\text { demyelination } \\
\%\end{array}$} & \multirow[t]{2}{*}{$\begin{array}{l}\text { Wallerian } \\
\text { degeneration } \\
\%\end{array}$} & \multirow{2}{*}{$\begin{array}{l}\text { Total } \\
\text { abnormal } \\
\text { fibres } \\
\% \\
\%\end{array}$} \\
\hline & & & & Fast & Average & & & & \\
\hline $\begin{array}{l}1 \\
2 \\
3 \\
4 \\
5\end{array}$ & $\begin{array}{l}25 \\
25 \\
27 \\
26 \\
23\end{array}$ & $\begin{array}{l}\mathbf{M} \\
\mathbf{M} \\
\mathbf{M} \\
\mathbf{M} \\
\mathbf{M}\end{array}$ & $\begin{array}{l}\text { BL } \\
\text { BL } \\
\text { BT } \\
\text { LL } \\
\text { LL }\end{array}$ & $\begin{array}{l}61 \\
61 \\
\text { Abser } \\
\text { Abser } \\
\text { Not d }\end{array}$ & $\begin{array}{l}52 \\
50\end{array}$ & $\begin{array}{l}40 \\
50 \\
50 \\
50 \\
50\end{array}$ & $\begin{array}{l}20 \\
15 \\
16 \\
30 \\
35\end{array}$ & $\begin{array}{r}17 \\
4 \\
12 \\
30 \\
2\end{array}$ & $\begin{array}{l}37 \\
19 \\
28 \\
60 \\
37\end{array}$ \\
\hline
\end{tabular}


Table 4 Group IV (Contacts of leprosy patients who were otherwise normal but where electrophysiological studies showed nerve conduction velocity at the lower limit of normal)

\begin{tabular}{|c|c|c|c|c|c|c|c|c|}
\hline \multirow[t]{2}{*}{$\begin{array}{l}\text { Serial } \\
\text { number }\end{array}$} & \multirow[t]{2}{*}{$\begin{array}{l}\text { Age } \\
(y r)\end{array}$} & \multirow[t]{2}{*}{ Sex } & \multicolumn{2}{|c|}{$\begin{array}{l}\text { Sensory nerve } \\
\text { conduction velocity } \\
(\mathrm{m} / \mathrm{s})\end{array}$} & \multirow[t]{2}{*}{$\begin{array}{l}\text { Number of } \\
\text { fibres studied }\end{array}$} & \multirow[t]{2}{*}{$\begin{array}{l}\text { Segmental } \\
\text { demyelination } \\
\%\end{array}$} & \multirow[t]{2}{*}{$\begin{array}{l}\text { Wallerian } \\
\text { degeneration } \\
\%\end{array}$} & \multirow{2}{*}{$\begin{array}{l}\text { Total } \\
\text { abnormal } \\
\text { fibres } \\
\text { o }\end{array}$} \\
\hline & & & Fast & Average & & & & \\
\hline 1 & 18 & $\mathbf{M}$ & 52 & 41 & 50 & 14 & 2 & 16 \\
\hline 2 & 45 & $\mathrm{~F}$ & 58 & 47 & 30 & 6.7 & 0 & 6.7 \\
\hline 3 & 6 & $\mathbf{M}$ & 64 & 48 & 30 & 6.7 & 0 & 6.7 \\
\hline 4 & 5 & $\mathbf{M}$ & 58 & 45 & 50 & 10 & 0 & 10 \\
\hline 5 & 22 & $\mathbf{M}$ & 58 & 48 & 50 & 10 & 0 & 10 \\
\hline
\end{tabular}

probably improved) method of recording sensory nerve action potentials in the branch of the radial cutaneous nerve to the index finger may help to confirm a diagnosis of leprosy and in the detection of disease in contacts of leprosy patients before any clinical or bacteriological evidence of leprosy.

This work was carried out in the Tata Department of Plastic Surgery with the help of grants from the Tata Trusts and the House of Tatas.

\section{References}

Antia, N. H., Mehta, L. N., Shetty, V. P., and Irani, P. F. (1975). Clinical, electrophysiological, quantitative, histological and ultrastructural studies of the index branch of the radial cutaneous nerve in leprosy. International Journal of Leprosy, 43, 106113.

Arnold, N., and Harriman, D. G. F. (1970). The incidence of abnormality in control human peripheral nerves studied by single axon dissection. Journal of Neurology, Neurosurgery, and Psychiatry, 33, 55-61.

Buchthal, F., and Rosenfalck, A. (1966). Action potentials of sensory nerves in man. Physiological and clinical aspects. The Horowitz Lectures (1965), Rehabilitation Monograph XXIX.

Buchthal, F., and Rosenfalck, A. (1971). Sensory potentials in polyneuropathy. Brain, 94, 241-262.

Dastur, D. K., and Razak, Z. A. (1971). Degeneration and regeneration in teased nerve fibres. I. Leprous neuritis. Acta Neuropathologica (Berlin), 18, 286298.

Dyck, P. G.. Gutretcht, J. A., Karnes, W. A., and Dale, A. J. D. (1968). Histologic and teased fiber measurement of sural nerve in disorders of lower motor and primary sensory neurons. Mayo Clinic Proceedings, 43, 81-123.

Job, C. K. (1971). Pathology of peripheral nerve lesions in lepromatous leprosy: a light and electron microscopic study. International Journal of Leprosy, 39, 251-267.

Lascelles, R. G., and Thomas, P. K. (1966). Changes due to age in internodal length in the sural nerve in man. Journal of Neurology, Neurosurgery, and Psychiatry, 29, 40-44.

Mehta, L. N., Shetty, P. V., Antia, N. H., and Irani, P. F. (1975). Quantitative histological and ultrastructural studies of the index branch of the radial cutaneous nerve in leprosy and its correlation with electrophysiological study. International Journal of Leprosy, 43, 256-264. 